\title{
DNA Base Composition, DNA-DNA Homology and Long-chain Fatty Acid Studies on Streptococcus thermophilus and Streptococcus salivarius
}

\author{
By J. A. E. FARROW AND M. D. COLLINS* \\ Department of Microbiology, National Institute for Research in Dairying, Shinfield, \\ Reading RG2 9AT, UK
}

(Received 18 August 1983; revised 10 October 1983)

DNA base composition, DNA-DNA homology and long-chain fatty acid studies were performed on Streptococcus thermophilus and Streptococcus salivarius. These species possess similar mol \% G + C values (about 37 to 41 ), long-chain fatty acid profiles and belong to a single DNA homology group. On the basis of the present and earlier studies it is proposed that Streptococcus thermophilus (Orla-Jensen) be reclassified as Streptococcus salivarius subsp. thermophilus comb. nov.

\section{INTRODUCTION}

The species Streptococcus thermophilus was described and named by Orla-Jensen (1919) during his studies on the bacteriology of lactic acid bacteria occurring in milk and dairy products. The taxonomic interrelationships of $S$. thermophilus have, however, always been controversial (see Jones, 1978). Sherman (1937) classified S. thermophilus in his 'viridans' division of the streptococci which encompassed S. bovis, S. equinus and S. salivarius. London \& Kline (1973), on the basis of FDP aldolase studies, grouped $S$. thermophilus with $S$. lactis and $S$. cremoris. The DNA-DNA homology studies of Ottogalli et al. (1979) however showed no close relationship between $S$. thermophilus and streptococci of serological group N. Indeed, DNArRNA hybridization studies (Garvie \& Farrow, 1981; Kilpper-Bälz et al., 1982) have shown that $S$. thermophilus is unrelated to $S$. lactis and $S$. cremoris at the generic level, but indicate that it is related at the generic level to $S$. bovis, $S$. equinus and $S$. salivarius. Furthermore, Kilpper-Bälz et al. (1982) showed high DNA-DNA homology (about 75 to $97 \%$ ) between four strains of $S$. thermophilus and $S$. salivarius. The recent numerical phenetic study of Bridge \& Sneath (1983) however showed no such close relationship between these species. Indeed, in the latter study $S$. thermophilus and $S$. salivarius were recovered as two quite distinct phena.

In the present study, mol \% $\mathrm{G}+\mathrm{C}$, DNA-DNA hybridization and long-chain fatty acid studies have been performed on a large number of $S$. thermophilus and $S$. salivarius strains in an attempt to clarify their taxonomic interrelationships.

\section{METHODS}

Strains. The test strains shown in Table 1 were obtained from the National Collection of Dairy Organisms (NCDO), Shinfield, Reading, UK.

DNA preparation and base composition determination. Preparation of DNA followed a modification (Farrow et al., 1983) of the method of Garvie (1976). The DNA base composition was estimated by thermal denaturation in standard saline citrate as described by Garvie (1978), using DNA from Leuconostoc mesenteroides NCDO 768 and Escherichia coli K12 NCDO 1984 as standards.

DNA-DNA hybridizations. These were performed under optimum conditions using the membrane filter technique described previously (Garvie et al., 1981).

Analysis of fatty acids. Strains were grown in YGPB (Garvie, 1978) at $30^{\circ} \mathrm{C}$ for $2 \mathrm{~d}$. Broth cultures were checked for purity on blood agar plates before harvesting by centrifugation. Cells were washed with distilled water and freeze-dried. Dry cells (about $50 \mathrm{mg}$ ) were examined using the acid methanolysis and thin-layer chromatography (TLC) procedure described by Minnikin et al. (1975). Fatty acid methyl esters were purified on Kieselgel 60 
plastic-backed sheets (Merck $5735 ; 10 \times 10 \mathrm{~cm})$ using petroleum ether (b.p. $\left.60-80^{\circ} \mathrm{C}\right) /$ diethyl ether $(85: 15$, v/v) as developing solvent. A Carlo Erba (Swindon, UK) Fractovap series 4160 flame-ionization gas chromatograph was used for the analysis of fatty acid methyl esters. Analyses were performed on a glass $25 \mathrm{~m} \mathrm{OV-1} \mathrm{(Carlo} \mathrm{Erba)} \mathrm{wall-}$ coated open tubular (WCOT) column, operated isothermally at $175^{\circ} \mathrm{C}$ using helium as carrier gas $\left(1.5 \mathrm{ml} \mathrm{min}^{-1}\right)$. The identity of individual esters was established by comparison of the retention times with those of standard straight-chain saturated and monounsaturated esters. The presence of unsaturated esters was confirmed by hydrogenation using $\mathrm{H}_{2}$ with $\mathrm{Pd}$ on charcoal as catalyst. Cyclopropane-ring containing esters were not affected by this treatment.

\section{RESULTS AND DISCUSSION}

The mol $\% \mathrm{G}+\mathrm{C}$ contents of the test strains are shown in Table 1. Streptococcus salivarius and $S$. thermophilus strains possessed $\mathrm{mol} \% \mathrm{G}+\mathrm{C}$ ranges of 39.5 to 41.0 and 37.2 to 39.8 , respectively. These data are in good agreement with the previous reports of about 38 to $42 \mathrm{~mol} \%$ $G+C$ within these species (Deibel \& Seeley, 1974; Kilpper-Bälz et al., 1982).

The results of DNA-DNA hybridization experiments are shown in Table 2. Streptococcus salivarius and $S$. thermophilus strains formed a single homology group, 61 to $100 \%$ related to the type strain of $S$. salivarius NCDO 1779, and 67 to $97 \%$ related to the type strain of $S$. thermophilus NCDO 573 under optimum hybridization conditions. The type strains of the two species were approximately $70 \%$ related to each other (Table 2). Strains of $S$. salivarius which lack the group $\mathrm{K}$ antigen were not significantly different from the group $\mathrm{K}$-containing strains in their homology values with either label. The type strains of $S$. mitis, $S$. mutans, $S$. oralis, $S$. sanguis and ' $S$. milleri' exhibited $<43 \%$ homology to $S$. salivarius NCDO 1779 and $<51 \%$ homology to $S$. thermophilus NCDO 573 (see Table 2). Kilpper-Bälz et al. (1982) recently reported high DNA homology (about 75 to $97 \%$ ) between two strains of $S$. salivarius and two strains of $S$. thermophilus. The high degree of overall DNA base sequence similarity between $S$. salivarius and $S$. thermophilus in the present study substantiates the findings of Kilpper-Bälz et al. (1982) and indicates that these taxa represent a single genetical species.

Whole-organism methanolysates of the test strains showed the presence upon TLC of single spots corresponding to non-hydroxylated long-chain fatty acid methyl esters. The nonhydroxylated fatty acids were composed of predominantly straight-chain saturated and monounsaturated acids. Cyclopropane-ring acids were either absent, or present in only trace amounts (Table 3). Streptococcus salivarius and $S$. thermophilus possessed similar fatty acid profiles with hexadecanoic $\left(C_{16: 0}\right)$, octadecenoic $\left(C_{18: 1}\right)$ and eicosenoic $\left(C_{20: 1}\right)$ acids constituting the major components. It is worth noting that the presence of substantial levels of oleic acid $\left(C_{18: 1}, \omega 9\right)$ in many of the strains were unexpected (Table 3). Members of the genus Streptococcus generally synthesize cis-vaccenic acid $\left(C_{18: 1}, \omega 7\right)$ (Collins et al., 1983; Farrow et al., 1983; Teixeria et al., 1983). Streptococcus mitis, $S$. oralis and $S$. sanguis differed from $S$. salivarius and $S$. thermophilus in lacking substantial levels (about 12 to $17 \%$ ) of $\mathrm{C}_{20: 1}$ fatty acids (Table 3 ). The presence of closely related fatty acid profiles within $S$. salivarius and $S$. thermophilus further supports the close relatedness between these taxa as shown by DNA-DNA homology studies (Kilpper-Bälz et al., 1982; Table 2).

Although $S$. salivarius and $S$. thermophilus are physiologically and biochemically very distinct, and have in the past been considered to be well-defined species (see Jones, 1978; Bridge \& Sneath, 1983), the present work and the earlier study of Kilpper-Bälz et al. (1982) show that they belong to a single DNA homology group. The apparently large number of phenetic differences between $S$. salivarius and $S$. thermophilus despite the high degree of overall DNA base sequence similarity is difficult to explain. It is possible that the two taxa share a large proportion of 'redundant' DNA or that the biochemical/physiological differences between the taxa may be due to their differing environments (i.e. phenetic divergence due to environmental pressure). Taking $70 \%$ homology under optimum hybridization conditions as the borderline for species differentiation, $S$. salivarius and $S$. thermophilus nevertheless represent a single genetical species. It is not however suggested that $S$. salivarius and $S$. thermophilus be reduced to synonymity. The separate identity of $S$. thermophilus should be retained since it is phenetically quite distinct from $S$. salivarius. We therefore formally propose that $S$. thermophilus (Orla-Jensen, 1919) be 
Table 1. Strain details and DNA base composition

\begin{tabular}{|c|c|c|c|}
\hline Strain designation & $\begin{array}{c}\text { NCDO } \\
\text { no. }\end{array}$ & Comments & $\begin{array}{c}\mathrm{Mol} \% \\
\mathrm{G}+\mathrm{C}\end{array}$ \\
\hline \multirow[t]{6}{*}{ Streptococcus salivarius } & 1779 & Type strain, group K, NCTC 8618 & $41 \cdot 0$ \\
\hline & 2107 & Cow's teeth & $40 \cdot 1$ \\
\hline & 2685 & Kiel 45807, group K (K. H. Schleifer, Münich, FRG) & $39 \cdot 7$ \\
\hline & 2686 & Kiel 21237 (K. H. Schleifer, Münich, FRG) & ND \\
\hline & 2700 & M 36 (J. Hardie, London, UK) & $39 \cdot 8$ \\
\hline & 2701 & A 385 , group K (J. Hardie, London, UK) & $39 \cdot 5$ \\
\hline \multirow[t]{11}{*}{ Streptococcus thermophilus } & 573 & Type strain, NCIB 8510 , ATCC 19258 & 39.6 \\
\hline & 271 & Cheese curd & 38.9 \\
\hline & 822 & German yogurt & $39 \cdot 7$ \\
\hline & 1409 & & $39 \cdot 3$ \\
\hline & 1469 & Bulgarian yogurt & $37 \cdot 2$ \\
\hline & 1611 & & $39 \cdot 3$ \\
\hline & 1968 & Bulgarian cheese, ferments lactose only & 39.7 \\
\hline & 2549 & Yogurt starter & $39 \cdot 7$ \\
\hline & 2635 & Gruyère cheese starter & $39 \cdot 2$ \\
\hline & 2687 & NCDO 489, DSM 20479 (K. H. Schleifer, Münich, FRG) & $39 \cdot 8$ \\
\hline & 2688 & Kiel 68323 (K. H. Schleifer, Münich, FRG) & $39 \cdot 2$ \\
\hline Streptococcus sanguis & 2064 & Type strain NCTC 7863 , ATCC 10556 & $43 \cdot 4$ \\
\hline Streptococcus mitis & 2495 & Type strain NCTC 3165 & $39 \cdot 5$ \\
\hline Streptococcus mutans & 2062 & Type strain NCTC 10449 & $37 \cdot 0$ \\
\hline Streptococcus oralis & 2680 & Type strain NCTC 11427 & $41 \cdot 3$ \\
\hline 'Streptococcus milleri' & 2077 & NCTC 10708 & $39 \cdot 0$ \\
\hline \multirow[t]{3}{*}{ Streptococcus sp. } & 1786 & 'Streptococcus salivarius' & $40 \cdot 4$ \\
\hline & 2104 & Cow's teeth & $40 \cdot 6$ \\
\hline & 2105 & Cow's teeth & $39 \cdot 2$ \\
\hline
\end{tabular}

Table 2. DNA homologies of $S$. salivarius and $S$. thermophilus with other streptococci using optimal hybridization conditions

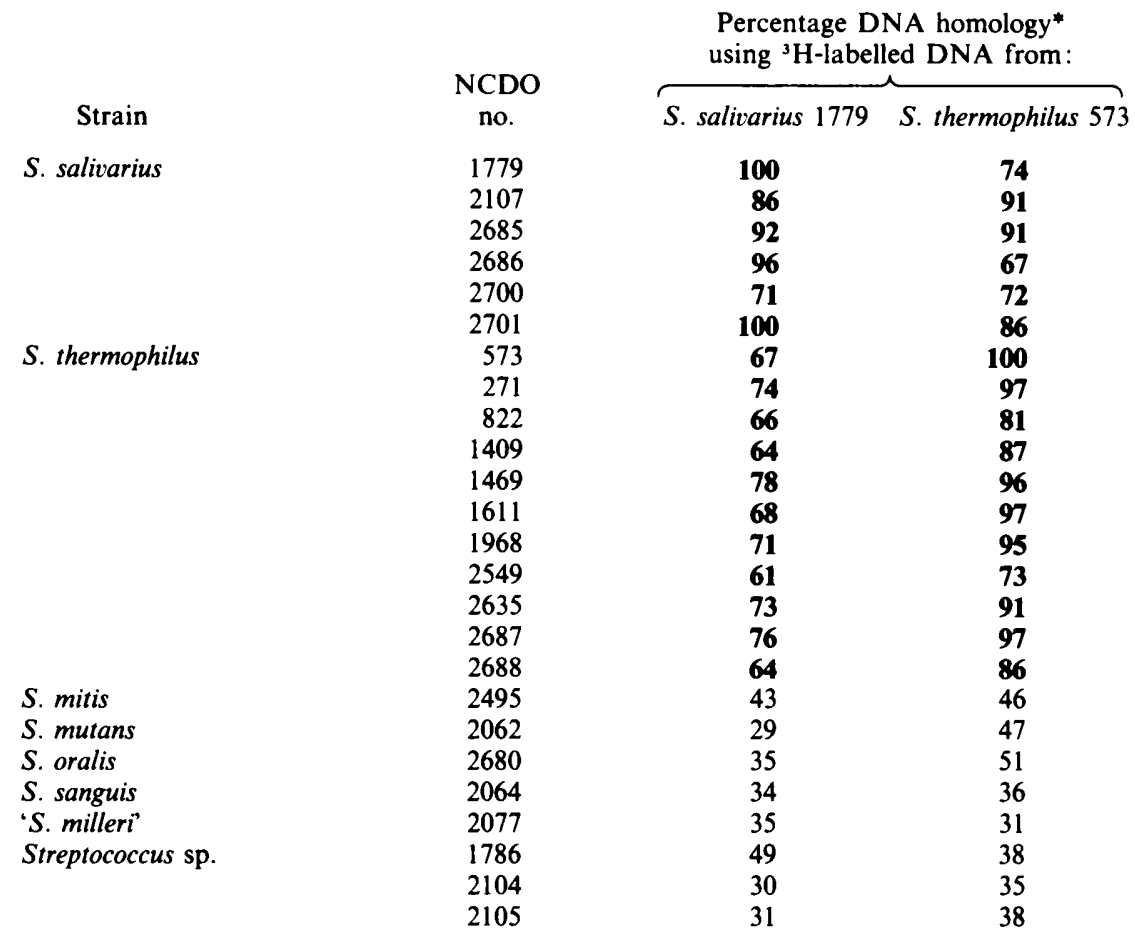

- Values $>60 \%$ are shown in bold print. 


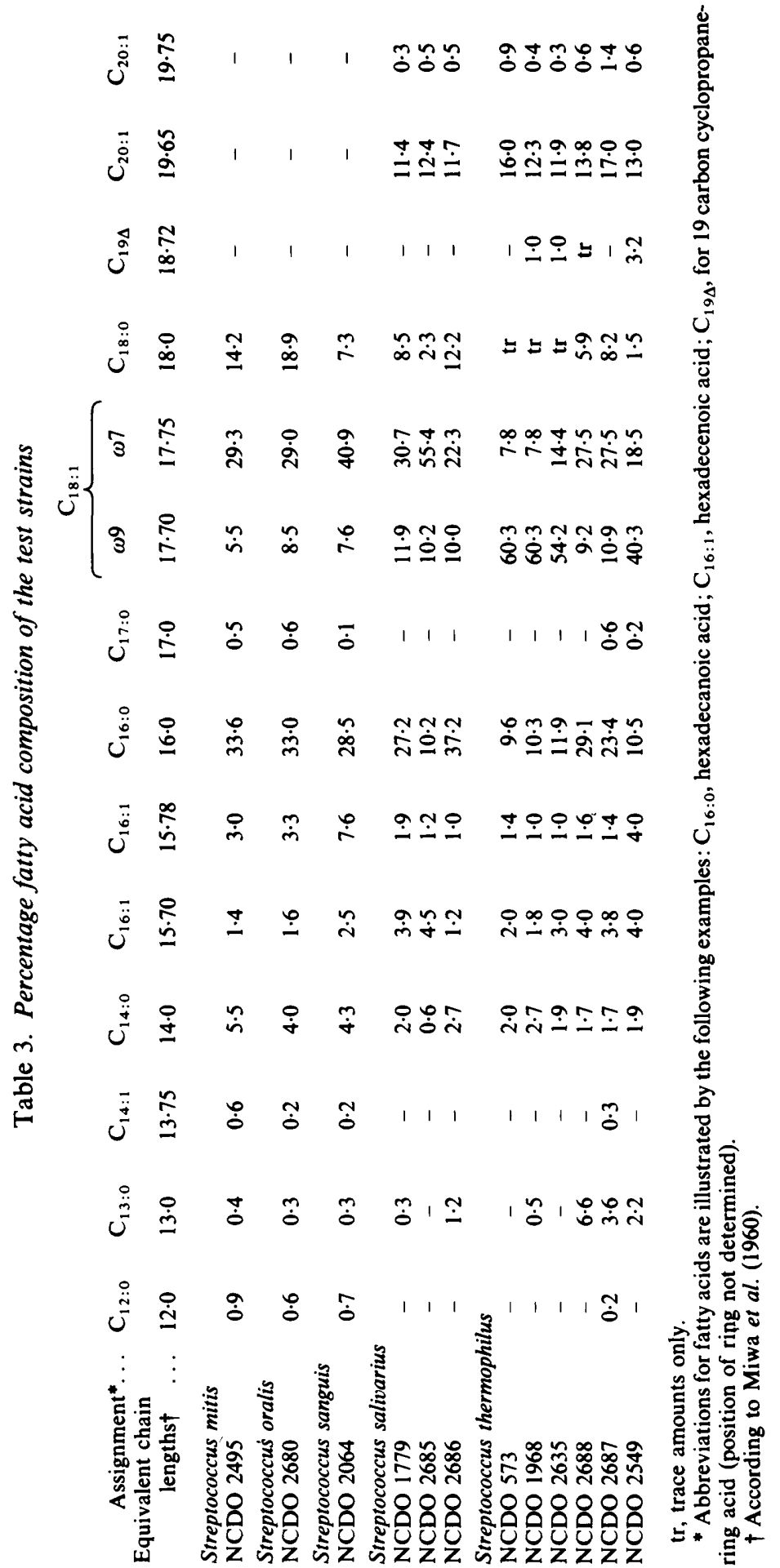


reclassified as $S$. salivarius subsp. thermophilus comb. nov., thereby automatically creating the subspecies $S$. salivarius subsp. salivarius.

Description of Streptococcus salivarius subsp. thermophilus comb. nov.

The following is based on the description of $S$. thermophilus in the 8th edition of Bergey's Manual of Determinative Bacteriology (Deibel \& Seeley, 1974) and the studies of Schleifer \& Kandler (1972), Kilpper-Bälz et al. (1982), Bridge \& Sneath (1983) and the present work.

Spherical or ovoid cells (about 0.8 to $1.0 \mu \mathrm{m}$ diam.) in pairs to long chains. Most strains produce a weak $\alpha$-reaction on blood agar. Catalase negative. Grows at $45^{\circ} \mathrm{C}$; many strains grow at $50^{\circ} \mathrm{C}$. No growth at $15^{\circ} \mathrm{C}$. Heat tolerance marked, survives heating at $65^{\circ} \mathrm{C}$ for $30 \mathrm{~min}$. Does not grow at $\mathrm{pH} 9.6$ or $0.1 \%$ methylene blue. Most strains do not grow in $2 \%(\mathrm{w} / \mathrm{v}) \mathrm{NaCl}$; no growth in $3 \% \mathrm{NaCl}$. Nutritionally exacting, requiring B-vitamins and some amino acids. Facultatively anaerobic. Chemo-organotroph: metabolism fermentative. Acid produced from fructose, glucose, lactose, mannose and sucrose. Acid not produced from $\mathrm{N}$-acetylglucosamine, adonitol, amygdalin, arabinose, cellobiose, dulcitol, erythritol, gluconate, glycerol, glycogen, inulin, maltose, mannitol, methyl D-glucoside, methyl D-mannoside, methyl D-xyloside, rhamnose, salicin, sorbitol, trehalose and xylose. Variable results may be obtained for arbutin, galactose, melezitose, melibiose, raffinose and ribose. Aesculin, arginine, casein, gelatin and hippurate are not hydrolysed. Starch hydrolysis is variable. DNAase and urease are not produced. Voges-Proskauer positive. Acid phosphatase, alkaline phosphatase, $\alpha$-galactosidase, cysteine arylamidase, $\beta$-glucuronidase, $\alpha$-glucosidase, $\beta$-glucosidase, $\alpha$-fucosidase, pyrrolidonylarylamidase, $N$-acetyl- $\beta$-glucosaminidase and valine arylamidase negative. $\beta$-Galactosidase and leucine arylamidase positive. Group A type peptidoglycan based upon lysine (type: Lysinealanine $_{\mathrm{n}}$ ). No group-specific antigen demonstrated. Menaquinones are absent. Major longchain fatty acids are $C_{16: 0}, C_{18: 1}$ and $C_{20: 1}$. The guanine plus cytosine content of DNA ranges from 37.2 to 40.3 as determined by melting temperature $\left(T_{m}\right)$.

Source: milk and milk products. Type strain: NCDO 573.

\section{REFERENCES}

Bridge, P. D. \& Sneath, P. H. A. (1983). Numerical taxonomy of Streptococcus. Journal of General Microbiology 129, 565-597.

Collins, M. D., Farrow, J. A. E., Phillips, B. A. \& KANDLER, O. (1983). Streptococcus garvieae sp. nov. and Streptococcus plantarum sp. nov. Journal of General Microbiology 129, 3427-3431.

DeIbel, R. H. \& SEeley, H. W., JR (1974). Genus Streptococcus. In Bergey's Manual of Determinative Bacteriology, 8th edn, pp. 490-509. Edited by R. E. Buchanan \& N. E. Gibbons. Baltimore: Williams \& Wilkins.

Farrow, J. A. E., Jones, D., Phillips, B. A. \& Collins, M. D. (1983). Taxonomic studies on some group D streptococci. Journal of General Microbiology 129, 1423-1432.

GARVIE, E. I. (1976). Hybridization between the deoxyribonucleic acids of some strains of heterofermentative lactic acid bacteria. International Journal of Systematic Bacteriology 26, 116-122.

GARVIE, E. I. (1978). Streptococcus raffinolactis (OrlaJensen and Hansen); a group $\mathbf{N}$ streptococcus found in raw milk. International Journal of Systematic Bacteriology 28, 190-193.

GARviE, E. I. \& FARrow, J. A. E. (1981). Sub-divisions within the genus Streptococcus using deoxyribonucleic acid/ribosomal ribonucleic acid hybridization. Zentralblatt für Bakteriologie, Parasitenkunde, Infektionskrankheiten und Hygiene (Abteilung I, Originale C) 2, 299-310.

Garvie, E. I., Farrow, J. A. E. \& Phillips, B. A. (1981). A taxonomic study of some strains of streptococci which grow at $10^{\circ} \mathrm{C}$ but not at $45^{\circ} \mathrm{C}$ including Streptococcus lactis and Streptococcus cremoris. Zentralblatt für Bakteriologie, Parasitenkunde, Infektionskrankheiten und Hygiene (Abteilung I, Originale C) 2, 151-165.

JONES, D. (1978). Composition and differentiation of the genus Streptococcus. In Streptococci, pp. 1-49. Edited by F. A. Skinner \& L. B. Quesnel. London: Academic Press.

KILPPER-BÄlZ, R., Fischer, G \& SCHLEIFER, K. H. (1982). Nucleic acid hybridization of group $\mathrm{N}$ and group D streptococci. Current Microbiology 7, 245250.

London, J. \& KLINE, K. (1973). Aldolase of lactic acid bacteria : a case history in the use of an enzyme as an evolutionary marker. Bacteriological Reviews 37, 453-478.

Minnikin, D. E., Alshamaony, L. \& Goodfellow, M. (1975). Differentiation of Mycobacterium, Nocardia and related taxa by thin-layer chromatographic analysis of whole-organism methanolysates. Journal of General Microbiology 88, 200-204.

Miwa, T. K., Mikolajczak, K. L., Earle, F. R. \& WolfF, I. A. (1960). Gas chromatographic characterization of fatty acids. Analytical Chemistry 32, 1739-1742.

Orla-Jensen, S. (1919). The Lactic Acid Bacteria. Copenhagen: Hølst. 
Ottogalli, G., Galli, N. \& Dellaglio, F. (1979). Taxonomic relationships between Streptococcus thermophilus and some other streptococci. Journal of Dairy Research 46, 127-131.

SChleifer, K. H. \& Kandler, O. (1972). Peptidoglycan types of bacterial cell walls and their taxonomic implications. Bacteriological Reviews 36, 407-477.
ShERMAN, J. M. (1937). The streptococci. Bacteriological Reviews 1, 3-97.

TeIXeria, L. M., Moss, C. W. \& Facklam, R. R. (1983). Gas liquid chromatography of the fatty acids of Streptococcus faecalis with a fused silica capillary column. FEMS Microbiology Letters 17, 257-260. 